\title{
Sistem Pendukung Keputusan Menentukan Tingkat Kepuasan Customer Terhadap Pelayanan Jasa Kebersihan Di Pt. Sas MenggunakanMetode Fuzzy Asosiative Memory
}

\author{
*Muhammad Dahria, Saiful Nur Arief, Ismawardi Santoso, Rini Kustini \\ Program Studi Sistem Informasi, STMIK Triguna Dharma \\ Jl. A.H Nasution No.73 Medan, Sumatera Utara, 20142 \\ `E-mail:m_dahria@trigunadharma.ac.id
}

\begin{abstract}
Abstrak
PT. Sukses Anugrah Sejahtera (SAS) adalah professional multi services company yang bergerak di bidang jasa cleaning service yang berpusat di Medan, berhasrat untuk dapat berkembang dengan menciptakan pelayanan yang prima kepada semua customer. harus mendapatkan tingkat kepuasan yang maksimal. Permasalahan yang terjadi pada saat ini adalah dalam menilai tingkat kepuasan customer masih menggunakan cara manual, yaitu dengan menyebarkan angket yang diprint dengan kertas HVS kepada setiap customer. Hal ini tentunya kurang efektif dikarenakan angket yang diberikan kepada customer bisa saja hilang atau robek. Sistem pendukung keputusan untuk menentukan tingkat kepuasan customer merupakan sistem yang berguna untuk membantu menghasilkan informasi yang mendukung bagi proses pengambilan keputusan mengenai besar kecilnya kepuasan customer terhadap perusahaan. Adapun metode yang akan digunakan dalam sistem pendukung keputusan adalah metode Fuzzy Assosiative Memory. Karena metode ini dapat menetukan nilai bobot untuk setiap atribut dengan tingkat akurasi yang baik.
\end{abstract}

Kata kunci : Sistem Pendukung Keputusan, Metode Fuzzy Tsukamoto, Menentukan Tingkat Kepuasan Customer

\begin{abstract}
PT. Sukses Anugrah Sejahtera (SAS) is a professional multi services company that operates in the field of cleaning service, based in Medan, desires to be able to develop by creating excellent service to all customers. must get the maximum level of satisfaction. The problem that occurs at this time is in assessing the level of customer satisfaction is still using the manual method, namely by distributing questionnaires that are printed with HVS paper to each customer. This is certainly less effective because the questionnaire given to the customer may be lost or torn. Decision support system to determine the level of customer satisfaction is a useful system to help produce information that supports the decision making process regarding the size of customer satisfaction with the company. The method to be used in decision support systems is the Fuzzy Associative Memory method. Because this method can determine the weight value for each attribute with a good degree of accuracy.
\end{abstract}

Keywords: Decision Support System, Tsukamoto Fuzzy Method, Determine Customer Satisfaction Level

\section{PENDAHULUAN}

Dalam sebuah kerjasama tentunya kedua belah pihak harusnya sama-sama mendapatkan keuntungan, baik itu secara materi ataupun pelayanan. Hal tersebut yang ingin diterapkan oleh PT. Sukses Anugrah Sejahtera (SAS). PT. Sukses Anugrah Sejahtera (SAS) adalah professional multi services company yang bergerak di bidang jasa cleaning service yang berpusat di Medan, berhasrat untuk dapat berkembang dengan menciptakan pelayanan yang prima kepada semua customer. 
Permasalahan yang terjadi pada saat ini adalah dalam menilai tingkat kepuasan customer masih menggunakan cara manual, yaitu dengan menyebarkan angket yang diprint dengan kertas HVS kepada setiap customer. Hal ini tentunya kurang efektif dikarenakan angket yang diberikan kepada customer bisa saja hilang atau robek.

Sistem pendukung keputusan untuk menentukan tingkat kepuasan customer merupakan sistem yang berguna untuk membantu menghasilkan informasi yang mendukung bagi proses pengambilan keputusan mengenai besar kecilnya kepuasan customer terhadap perusahaan. Adapun metode yang akan digunakan dalam sistem pendukung keputusan adalah metode Fuzzy Assosiative Memory.

\section{METODE PENELITIAN}

\subsection{Kepuasan Pelanggan}

Philip Kotler mengemukakan dalam bukunya manajemen pemasaran bahwa kepuasan adalah perasaan senang atau kecewa seseorang yang muncul setelah membandingkan antara persepsi/kesannya terhadap kinerja (atau hasil) suatu produk dan harapan-harapannya [8].

Kepuasan pelanggan merupakan kontribusi pada sejumlah aspek krusial, seperti terciptanya loyalitas pelanggan, meningkatnya reputasi perusahaan, berkurangnya elastisitas harga, berkurangnya biaya transaksi masa depan, dan meningkatnya efisiensi dan produktifitas karyawan.

\subsection{Sistem Pendukung Keputusan}

Sistem pendukung keputusan merupakan suatu penerapan sistem informasi yang ditujukan untuk membantu pimpinan d keputusan menggabungkan kemampu roses pengambilan keputusan. Sistem pendukung iputer dalam pelayanan interaktif dengan pengolahan data yang memanfaatkan model atau aturan penyeleksian yang tidak terstruktur [5].

\section{$2.3 \quad$ Logika Fuzzy}

Menurut Sri Kusumadewi dan Hari Purnomo [3] Logika fuzzy termasuk salah satu komponen untuk membentuk soft computing. Prof. Lofti A.Zadeh merupakan orang pertama yang memperkenalkan logika fuzzy pada tahun 1965, Dasar logika fuzzy adalah teori himpunan fuzzy. Pada teori himpunan fuzzy, pesranan derajat keanggotaan sebagai penentu keberadaan elemen dalam suatu himpunan sangatlah penting.

Nilai keanggotaan atau derajat keanggotaan atau membership function menjadi ciri utama dari penalaran dengan logika fuzzy tersebut.

\subsubsection{Fungsi Keanggotaan}

Fungsi keanggotaan merupakan kurva yang berfungsi untuk menunjukkan pemetaan titik-titik input data ke dalam nilai keanggotaannya atau derajat keanggotaan, yang memiliki interval antara 0 sampai 1 . Terdapat beberapa fungsi yang bisa digunakan, diantaranya adalah representasi kurva trapesium, representasi kurva segitiga, representasi linier, representasi kurva-s, representasi kurva bentuk bahu serta representasi kurva bentuk lonceng [6].

Terdapat beberapa operasi yang didefinisikan secara khusus untuk mengkombinasi dan memodifikasi himpunan fuzzy. Nilai keanggotaan sebagai hasil dari operasi dua himpunan disebut dengan a-predikat atau fire streng. Terdapat tiga operator fuzzy yang diciptakan oleh Zadeh, yaitu: operator AND, operator OR, dan operator NOT. Salah satu cara yang dapat digunakan untuk mendapatkan nilai keanggotaan adalah dengan melalui pendekatan fungsi representasi linear. Pada representasi linear, pemetaan input ke derajat keanggotaannya digambarkan sebagai suatu garis lurus. Ada 2 keadaan himpunan Fuzzy linear, yaitu:

4. $\quad$ Representasi Linear Naik

Kenaikan himpunan dimulai pada nilai domain yang memiliki derajat keanggotaan nol (0) bergerak ke kanan menuju ke nilai domain yang memiliki derajat keanggotaan lebih tinggi. 
Fungsi keanggotaan:

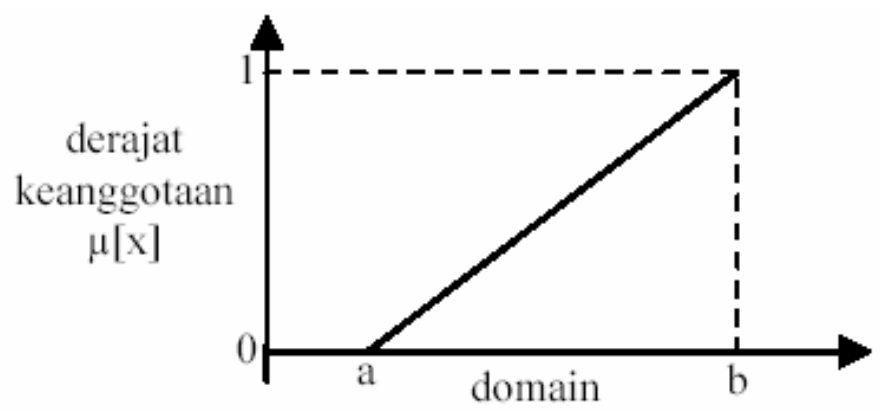

Gambar 1 Representasi Linear Naik

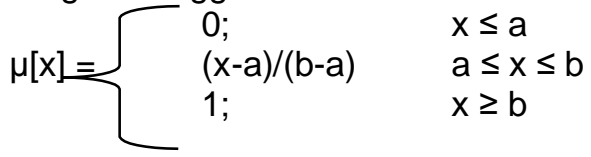

5.

Representasi Linear Turun

Representasi linear turun merupakan kebalikan dari linear naik. Garis lurus dimulai dari nilai domain dengan derajat keanggotaan tertinggi pada sisi kiri, kemudian bergerak menurun ke nilai domain yang memiliki derajat keanggotaan lebih rendah.

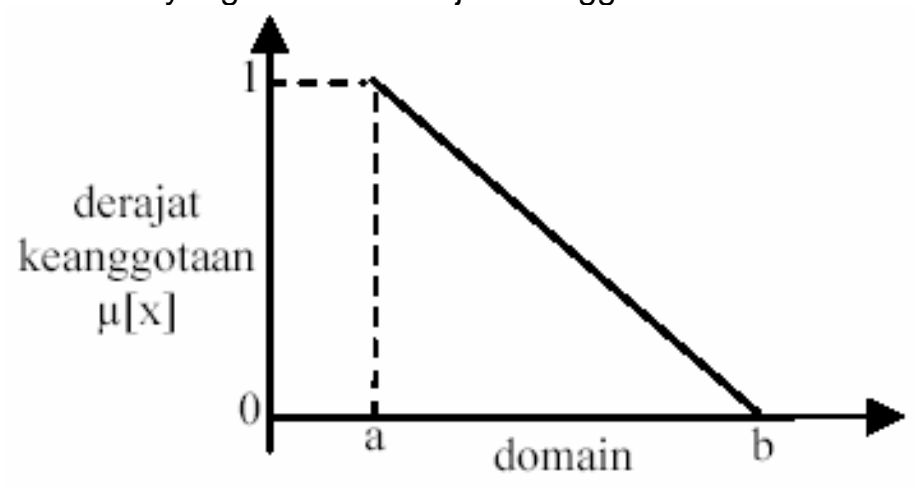

Fungsi keanggotaan:

Gambar 2 Representasi Linear Turun

$$
\mu[x]= \begin{cases}(b-x) /(b-a) ; & a \leq x \leq b \\ 0 ; & x \geq b\end{cases}
$$

\subsection{Metode Fuzzy Associative Memory}

1 Menurut Kusumadewi dan Purnomo, Fuzzy Associative Memory (FAM) adalah sebuah sistem fuzzy yang memetakan antara satu himpunan fuzzy ke himpunan fuzzy yang lain.

2 FAM merupakan versi fuzzy dari Bidirectional Associative Memory (BAM). FAM sederhana akan memetakan suatu aturan fuzzy atau himpunan pasangan ( $\mathrm{Ai}, \mathrm{Bj})$ yang menghubungkan himpunan fuzzy $\mathrm{Bj}$ ke himpunan fuzzy Ai.

3 Fuzzy Associative Memory (FAM) pertama kali dipublikasikan oleh Bart Kosko. FAM adalah sebuah sistem yang memetakan antara satu himpunan fuzzy ke himpunan fuzzy yang lain. Secara umum, arsitektur dari sebuah sistem FAM adalah seperti pada gambar berikut: 


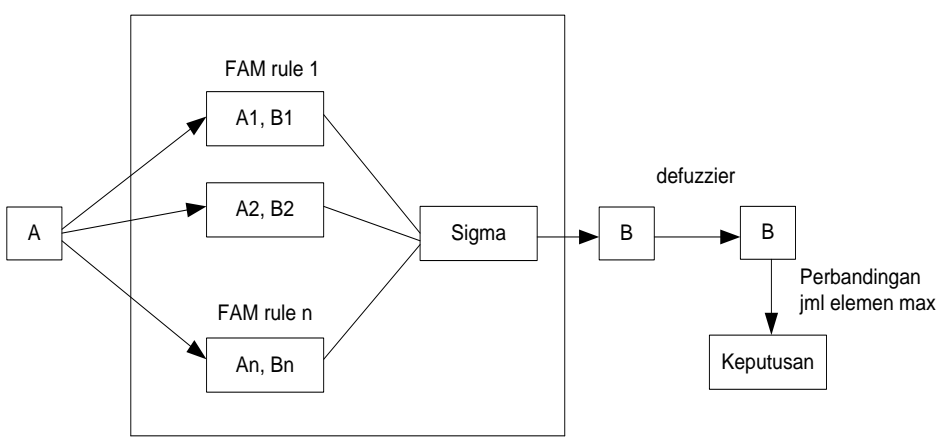

Gambar 3 Arsitektur FAM

\section{ANALISA DAN PEMBAHASAN}

\subsection{Analisa Permasalahan}

Karaoke Family Deli Center adalah suatu usaha bisnis yang bergerak dibidang dunia hiburan yang sedang berkembang. Dalam memberikan pelayanan hiburan dan karaoke sering kali Karaoke Family Deli Center mengalami kesulitan dalam mengetahui kepuasan pelanggan guna untuk mengevaluasi pelayanan, pihak Karaoke Family Deli Center hanya melihat secara manual dari beberapa faktor terkait dengan kepuasan pelanggan tersebut tanpa mengetahui apakah sebenarnya pelanggan puas atau kecewa.

\subsection{Algoritma Sistem}

Algoritma (tahapan) dalam proses perhitungan menggunakan metode Fuzzy associative memory adalah sebagai berikut :

1. Menentukan Kriteria Penilaian

2. Menentukan Alternatif Yang Akan Dinilai

3. Melakukan Proses Fuzzyfikasi

4. Melakukan Proses Inferensi Rule

5. Melakukan Proses Defuzzyfikasi

6. Proses Perangkingan Alternatif

\subsubsection{Menentukan Kriteria Penilaian}

Dalam sistem pendukung keputusan menentukan tingkat kepuasan customer, maka harus ditetapkan kriteria-kriteria yang digunakan sebagai acuan untuk penilaian dalam pengambilan keputusan. Kriteria-kriteria tersebut dapat dilihat pada tabel di bawah ini :

Tabel 1 Kriteria-Kriteria Yang Ditetapkan

\begin{tabular}{|c|l|c|}
\hline No & \multicolumn{1}{|c|}{ Kriteria } & Kode Kriteria \\
\hline 1 & Hasil kerja karyawan dalam membersihkan ruangan & K01 \\
\hline 2 & $\begin{array}{l}\text { Kecepatan karyawan dalam menangani keluhan } \\
\text { customer }\end{array}$ & K02 \\
\hline 3 & Kesopanan karyawan terhadap customer & K03 \\
\hline 4 & Penampilan karyawan selama bekerja & K04 \\
\hline 5 & Komunikasi karyawan dengan pelanggan & K05 \\
\hline
\end{tabular}

\subsubsection{Menentukan Alternatif}

Tahapan penilaian menentukan tingkat kepuasan customer dimulai dari proses penentuan alternatif yang akan dinilai, kemudian setiap alternatif diberi nilai. Lalu akan dilakukan proses fuzzy associative memory untuk setiap kriteria pada masing-masing alternatif. Berikut dibawah ini data alternatif customer yang akan diperoleh.

Tabel 2 Data Customer

\begin{tabular}{|c|c|l|}
\hline No & Kode Customer & \multicolumn{1}{|c|}{ Nama Customer } \\
\hline 1 & C-01 & Indra Syahputra \\
\hline 2 & C-02 & Stefanus Sianturi \\
\hline 3 & C-03 & Ahmad Najib \\
\hline 4 & C-04 & Ayu Lestari \\
\hline 5 & C-05 & Dian Permadi \\
\hline
\end{tabular}




\begin{tabular}{|c|l|l|}
\hline 6 & C-06 & Ryan Kurniawan \\
\hline 7 & C-07 & Riski Rahmadani \\
\hline 8 & C-08 & Safrida Lubis \\
\hline 9 & C-09 & Ahmad Zakaria \\
\hline 10 & C-10 & Geovani \\
\hline
\end{tabular}

Berikut dibawah ini data kriteria pada setiap customer. Seperti yang ditampilkan pada tabel 3 sebagai berikut.

Tabel 3 Data Kriteria Customer

\begin{tabular}{|c|c|c|c|c|c|c|}
\hline No & $\begin{array}{c}\text { Kode } \\
\text { Customer }\end{array}$ & $\begin{array}{c}\text { Hasil } \\
\text { kerja }\end{array}$ & $\begin{array}{c}\text { Kece } \\
\text { patan }\end{array}$ & Kesopanan & Penampilan & Komunikasi \\
\hline 1 & C-01 & 65 & 75 & 75 & 80 & 65 \\
\hline 2 & C-02 & 75 & 60 & 75 & 70 & 75 \\
\hline 3 & C-03 & 85 & 85 & 75 & 70 & 80 \\
\hline 4 & C-04 & 85 & 85 & 70 & 75 & 80 \\
\hline 5 & C-05 & 75 & 70 & 70 & 80 & 70 \\
\hline 6 & C-06 & 70 & 60 & 70 & 75 & 65 \\
\hline 7 & C-07 & 65 & 85 & 80 & 85 & 75 \\
\hline 8 & C-08 & 60 & 70 & 80 & 85 & 75 \\
\hline 9 & C-09 & 80 & 65 & 75 & 70 & 70 \\
\hline 10 & C-10 & 60 & 70 & 65 & 70 & 80 \\
\hline
\end{tabular}
berikut:

Kriteria dan nilai bobot yang akan digunakan dalam proses penilaian adalah sebagai

Tabel 4 Nilai Bobot Kriteria Penilaian

\begin{tabular}{|c|l|c|}
\hline No & \multicolumn{1}{|c|}{ Keterangan } & Bobot \\
\hline 1 & Sangat Baik & $\geq 80$ \\
\hline 2 & Baik & $75-79$ \\
\hline 3 & Cukup Baik & $70-74$ \\
\hline 4 & Kurang Baik & $\leq 69$ \\
\hline
\end{tabular}

Berikut digambarkan nilai bobot setiap kriteria dalam bentuk kurva seperti dibawah ini.

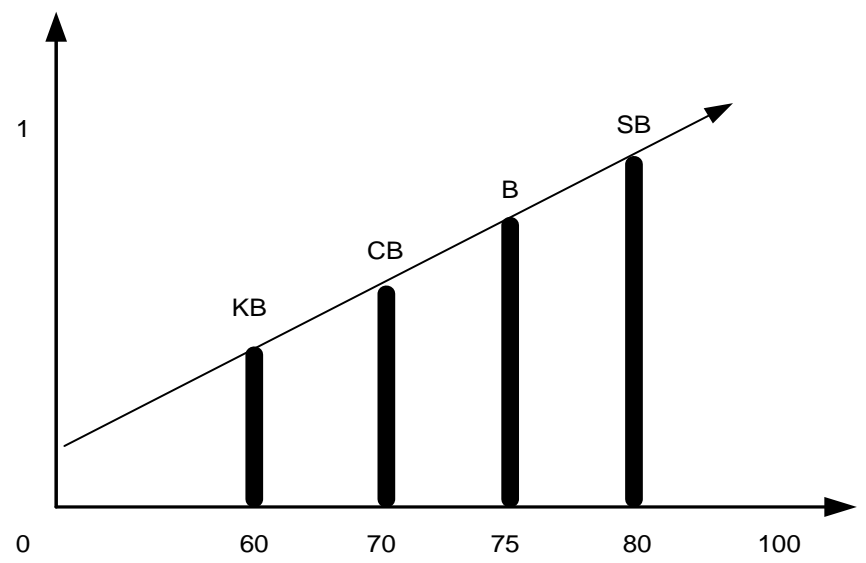

Gambar 4 Kurva Kriteria

Dalam melakukan perhitungan dengan metode fuzzy associative memory diperlukan nilai kriteria yang bersifat nominal/angka. Sehingga diperoleh data nilai kriteria Customer setelah dikonversi sebagai berikut.

Tabel 5 Nilai Kriteria Customer Setelah Konversi 


\begin{tabular}{|c|c|c|c|c|c|c|}
\hline No & $\begin{array}{c}\text { Kode } \\
\text { Customer }\end{array}$ & $\begin{array}{c}\text { Hasil } \\
\text { kerja }\end{array}$ & $\begin{array}{c}\text { Kece } \\
\text { patan }\end{array}$ & $\begin{array}{c}\text { Keso } \\
\text { panan }\end{array}$ & $\begin{array}{c}\text { Penam } \\
\text { pilan }\end{array}$ & $\begin{array}{c}\text { Komu } \\
\text { nikasi }\end{array}$ \\
\hline 1 & C-01 & 65 & 75 & 75 & 80 & 65 \\
\hline 2 & C-02 & 75 & 60 & 75 & 70 & 75 \\
\hline 3 & C-03 & 85 & 85 & 75 & 70 & 80 \\
\hline 4 & C-04 & 85 & 85 & 70 & 75 & 80 \\
\hline 5 & C-05 & 75 & 70 & 70 & 80 & 70 \\
\hline 6 & C-06 & 70 & 60 & 70 & 75 & 65 \\
\hline 7 & C-07 & 65 & 85 & 80 & 85 & 75 \\
\hline 8 & C-08 & 60 & 70 & 80 & 85 & 75 \\
\hline 9 & C-09 & 80 & 65 & 75 & 70 & 70 \\
\hline 10 & C-10 & 60 & 70 & 65 & 70 & 80 \\
\hline
\end{tabular}

\subsubsection{Melakukan Proses Fuzzyfikasi}

Berdasarkan unit penalaran yang terdapat pada inferensi fuzzy, maka akan terbentuk aturan-aturan yang berjumlah 10 rule, rule tersebut bisa diganti sesuai kebijakan. Berikut dijelaskan pada tabel dibawah ini.

Tabel 6 Pengujian Validitas Data Rule Yang Digunakan

\begin{tabular}{|c|c|c|c|c|c|}
\hline Rule & K1 & K2 & K3 & K4 & K5 \\
\hline 1 & Rendah & Rendah & Rendah & Rendah & Rendah \\
\hline 2 & Rendah & Rendah & Rendah & Tinggi & Tinggi \\
\hline 3 & Tinggi & Rendah & Rendah & Rendah & Rendah \\
\hline 4 & Rendah & Tinggi & Rendah & Rendah & Rendah \\
\hline 5 & Rendah & Rendah & Tinggi & Rendah & Tinggi \\
\hline 6 & Rendah & Rendah & Tinggi & Tinggi & Tinggi \\
\hline 7 & Tinggi & Rendah & Rendah & Tinggi & Tinggi \\
\hline 8 & Tinggi & Tinggi & Rendah & Rendah & Rendah \\
\hline 9 & Rendah & Tinggi & Tinggi & Rendah & Rendah \\
\hline 10 & Rendah & Tinggi & Rendah & Tinggi & Tinggi \\
\hline
\end{tabular}

Kriteria dan nilai bobot yang akan digunakan dalam proses penyeleksian sebagai berikut:

Tabel 7 Nilai Minimum dan Maksimum Kriteria

\begin{tabular}{|c|l|c|c|}
\hline No & Nilai Kriteria & Interval & Variabel \\
\hline 1 & Nilai Minimum & 40 & Rendah \\
\hline 2 & Nilai Maksimum & 100 & Tinggi \\
\hline
\end{tabular}

Dari contoh data tabel 7 (tabel nilai kriteria Customer) diambil salah satu data dari Customer yang akan diuji nilainya yaitu data Customer C-01 bernama Indra Syahputra untuk diperhitungkan nilai menentukan tingkat kepuasan customer dengan menggunakan metode Fuzzy associative memory dengan ketentuan data sebagai berikut :
1. Nilai Kriteria Hasil kerja
$: 65$
2. Nilai Kriteria Kecepatan
$: 75$
3. Nilai Kriteria Kesopanan : :75
4. Nilai Kriteria Penampilan $: 80$
5. Nilai Kriteria Komunikasi $: 65$ 
Proses fuzzyfikasi dilakukan untuk mendapatkan nilai crisp fungsi keanggotaan pada setiap kriteria yang dihitung dengan rumus sebagai berikut :

$$
\mu[\mathrm{x}]= \begin{cases}0 ; & x \leq a \\ (x-a) /(b-a) ; & a \leq x \leq b \\ 1 ; & x=b\end{cases}
$$

Dimana :

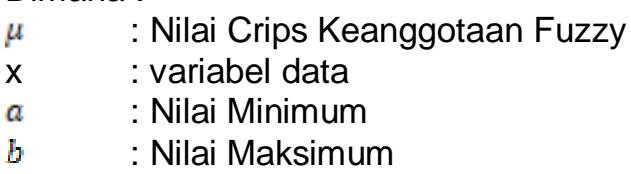

\subsubsection{Tampilan Menu Utama}

Setelah proses login berhasil, admin akan diarahkan ke menu utama dimana terdapat enam (4) sub menu utama yaitu File, Penilaian, Laporan dan Menu Keluar. Berikut dibawah ini tampilan form menu utama.

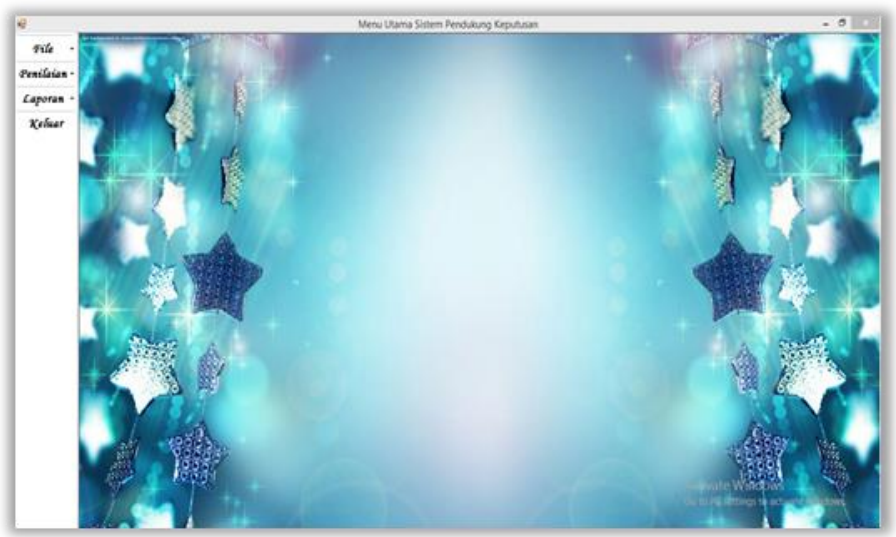

\subsubsection{Tampilan Input Data Customer}

Gambar 1 Tampilan Menu Utama

Pada input data customer yang dimaksud adalah proses menambah, mengubah, menyimpan, dan menghapus data customer yang terdapat pada database. Form customer yang ditunjukkan pada gambar 7 dibawah ini.

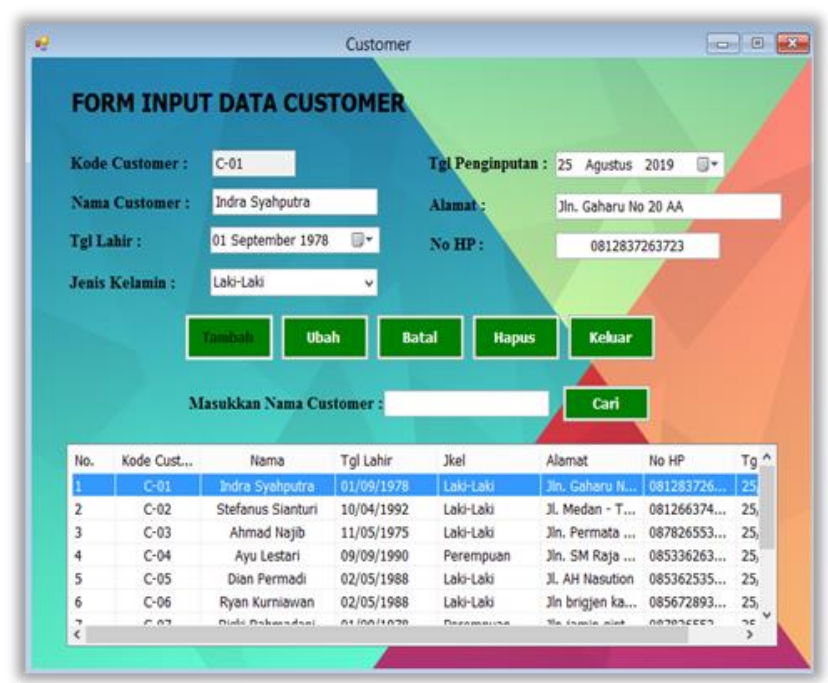

Gambar 2 Tampilan Input Data Customer 


\subsubsection{Tampilan Input Nilai Kriteria}

Pada input nilai kriteria Customer yang dimaksud adalah proses menambah, mengubah, menyimpan, dan menghapus nilai kriteria Customer yang terdapat pada database. Seperti yang ditunjukkan pada gambar dibawah ini.

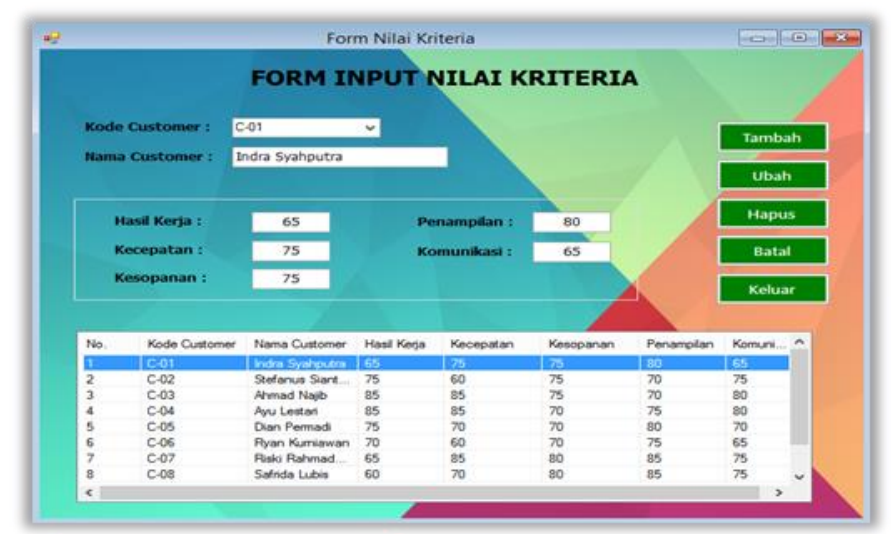

Gambar 3 Tampilan Input Nilai Kriteria Customer

\subsubsection{Tampilan Form Proses}

Pada form proses keputusan merupakan tampilan antarmuka untuk memproses data nilai kriteria dari tiap-tiap kriteria yang telah dimasukkan pada sistem ini. Berikut adalah gambar hasil implementasi dari rancangan antarmuka form proses keputusan.

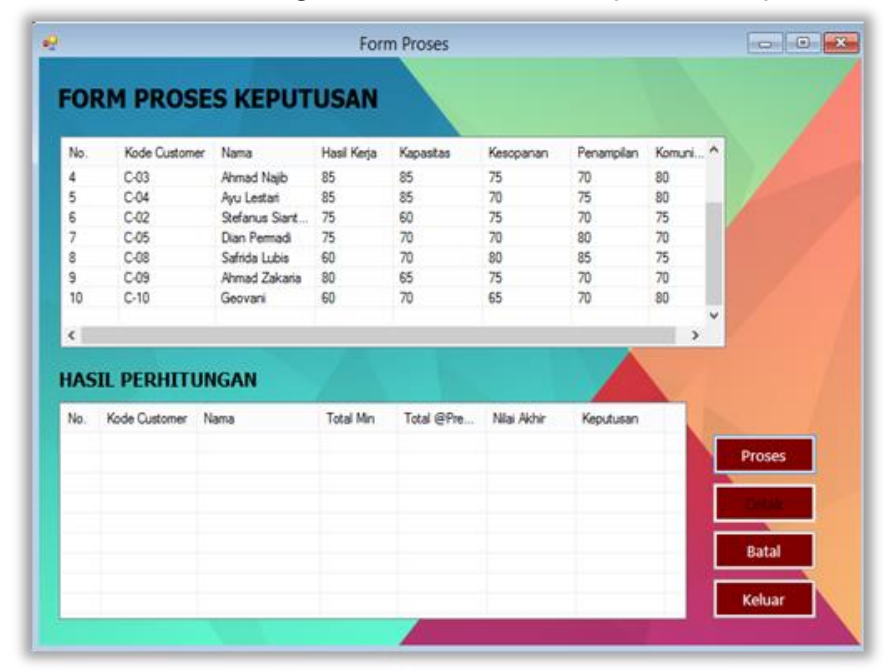

Gambar 4 Tampilan Awal Form Proses Keputusan 


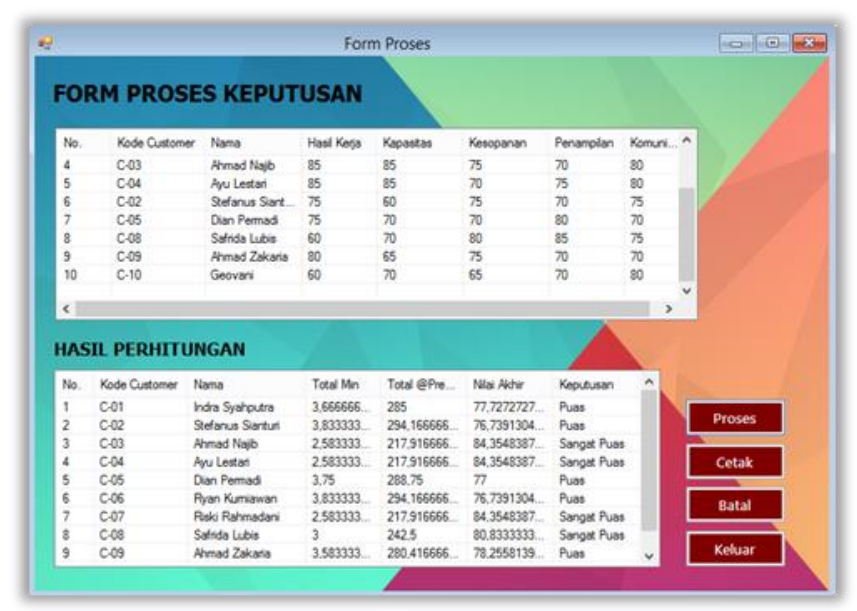

Gambar 5 Tampilan Hasil Form Proses Keputusan

\section{KESIMPULAN}

Berdasarkan pembahasan dan evaluasi dari bab terdahulu, maka dapat ditarik kesimpulan sebagai berikut :

1. Metode Fuzzy Associative Memory mampu menyelesaikan permasalahan yang ada pada PT. SAS dalam menentukan tingkat kepuasan customer, karena metode Fuzzy Associative Memory yang dalam implementasinya akan menghasilkan nilai akhir alternatif berdasarkan perhitungan setiap kriteria yang ada.

2. Sistem pendukung keputusan tingkat kepuasan customer pada PT. SAS dengan menggunakan metode Fuzzy Associative Memory berhasil dibangun dan berjalan dengan baik.

3. Pengimplementasian sistem pendukung keputusan dilakukan dengan cara menginstall sistem tersebut pada komputer admin yang akan menggunakan sistem untuk menentukan tingkat kepuasan customer.

\section{REFERENSI}

[1] Artika, Rini. (Agustus 2013). Penerapan Analitycal Hierarcy Process Dalam Pendukung Keputusan Penilaian Kinerja Guru SD Negeri. Jurnal Pelita Informatika. Vol 4 (3). Hal 124.

[2] A.S Rosa, Salahuddin M. (2015). Pembelajaran Rekayasa Perangkat Lunak (Terstruktur dan Berorientasi Objek). Penerbit Modula : Bandung.

[3] Kusumadewi, Sri. (Maret 2016). Implementasi Logika Fuzzy Tahani Untuk Model Sistem Pendukung Keputusan Evaluasi Kinerja Karyawan. Jurnal Pilar Nusa Mandiri. Vol XII (1). Hal 1.

[4] Magdalena, Hilyah. (Maret 2012). Sistem Pendukung Keputusan Untuk Menentukan Mahasiswa Lulusan Terbaik Studi Kasus STMIK Atma Luhur Pangkalpinang. Seminar Nasional Teknologi Informasi dan Komunikasi. Vol 1 (2). Hal 50.

[5] Malisa. (Maret 2016). Sistem Pendukung Keputusan Penentuan Prioritas Perbaikan Jalan Menggunakan Metode SAW. Seminar Nasional Sistem Informasi. Vol 1 (2). Hal 71.

[6] Rofiq, Muhammad. (Februari 2013). Perancangan Manajemen Bandwidth Internet Menggunakan Metode Fuzzy Sugeno. Jurnal IImiah Teknologi dan Informasi. Vol 7 (1). Hal 5.

[7] Rohayani, Hetty. (April 2013). Analisis Sistem Pendukung Keputusan Dalam Memilih Program Studi Menggunakan Metode Logika Fuzzy. Jurnal Sistem Informasi. Vol 5 (1). Hal 535.

[8] Sholeha, Ludviyatus. (Desember 2018). Pengaruh Kualitas Pelayanan Terhadap Kepuasan Pelanggan di AHASS Sumber Jaya Kabupaten Banyuwangi. Jurnal Pendidikan Ekonomi. Vol 1 (1). Hal 18.

[9] Syahrizal, Muhammad. (Agustus 2012). Perancangan Sistem Aplikasi Pembuatan Roster Mata Kuliah Pada Perguruan Tinggi. Jurnal Informatika. Vol1 (1). Hal 65. 
[10] Wicaksono, Agung. (Agustus 2014). Sistem Pendukung Keputusan Penerimaan Beasiswa Dengan Algoritma Fuzzy Tsukamoto di SMP Al-Islam 1 Surakarta. Jurnal IImiah Sinus. Vol 1 (1). Hal 14.

[11] Yudivianto, Agung. (Agustus 2010). Strategi Pendanaan dan Peminjaman Modal Usaha. Jurnal Ekonomi Universitas Indonesia. Vol 1 (1). Hal 11./ 